\title{
CSR Business as Usual? The Case of the Tobacco Industry
}

\author{
Guido Palazzo \\ Ulf Richter
}

\begin{abstract}
Tobacco companies have started to position themselves as good corporate citizens. The effort towards CSR engagement in the tobacco industry is not only heavily criticized by anti-tobacco NGOs. Some opponents such as the the World Health Organization have even categorically questioned the possibility of social responsibility in the tobacco industry. The paper will demonstrate that the deep distrust towards tobacco companies is linked to the lethal character of their products and the dubious behavior of their representatives in recent decades. As a result, tobacco companies are not in the CSR business in the strict sense. Key aspects of mainstream CSR theory and practice such as corporate philanthropy, stakeholder collaboration, CSR reporting and self-regulation, are demonstrated to be ineffective or even counterproductive in the tobacco industry. Building upon the terminology used in the leadership literature, the paper proposes to differentiate between transactional and transformational CSR arguing that tobacco companies can only operate on a transactional level. As a consequence, corporate responsibility in the tobacco industry is based upon a much thinner approach to CSR and has to be conceptualized with a focus on transactional integrity across the tobacco supply chain.
\end{abstract}

KEY WORDS: CSR, corporate philanthropy, organizational legitimacy, tobacco industry, the common good, integrity, transactional CSR, transformational CSR

Guido Palazzo is Assistant Professor for Business Ethics at the University of Lausanne (Switzerland). He graduated in Business Administration at the University of Bamberg (Germany) and earned his PhD in Political Philosophy (1999) from the University of Marburg (Germany). His research interests are in Corporate Social Responsibility, Corporate Branding, Democratic Theory, and Organizational Ethics.

Ulf Richter is a doctoral student at the University of Lausanne. He is writing his thesis on Corporate Social Responsibility, conceptualizing the concept from a multidisciplinary perspective. He has studied in Germany, Peru and the US, and graduated from the European Business School, Oestrich-Winkel, majoring in International Management and Real Estate.
The tobacco industry has entered the CSR debate. BAT (2003) has published its first CSR report 2002/2003 and has been awarded for it. Philip Morris International has published substantial information on its CSR-related position and activities on its webpage. Imperial Tobacco has set up a webpage dedicated to CSR providing information on youth smoking, smuggling, stakeholder dialogue and human rights issues. Japan Tobacco publishes at least information on what they consider their corporate social responsibility. Obviously, even tobacco companies strive for the status of good corporate citizens. In its recruiting activities, for instance, Philip Morris has communicated its goal to become "the most successful, respected and socially responsible global consumer products company".

It has become an established phenomenon that critical NGOs react to CSR communication by highlighting the shortcomings. Companies that report on their engagement are almost immediately confronted with the critique of opposed NGOs. BPs claim to be now the world largest producer of solar energy, for instance, was countered with the allegation that the only reason for this was that BP bought the solar energy producer Solarex for a neglectable $\$ 45$ million in comparison to its $\$ 26.5$ billion investment in the major US fuel retailer ARCO (Bruno, 2000). CSR reports are answered by "alternative" CSR reports or analyses (e.g. for McDonald's CSR report see Tapscott and Ticoll, 2003, p. 179). Anecdotic CSR reports are answered by anecdotic counter-examples. Therefore, it was of no surprise that the first CSR report in the tobacco industry motivated comparable reactions from antitobacco NGOs (cf. foremost Rimmer, 2004). This is the normal procedure in the currently developing dynamic of civil society and economic actors and it can be regarded as a crucial driver for a continually improved CSR performance. However, in the case 
of the tobacco industry, leading opponents such as the World Health Organization (WHO) (2003) have categorically questioned the possibility of social responsibility in the tobacco industry, describing it as an "inherent contradiction".

The tobacco industry is different from other industries for two reasons. The first reason is linked to the products it sells. Today, there is no doubt that smoking is both addictive and lethal. Scientific research has shown that one in two long-term smokers will die prematurely as a result of smoking half of them middle-aged. Obviously, the interests of the tobacco industry run counter to the social good (Michalos, 1997). The second reason is linked to the past behavior of the industry's representatives. They have lost credibility due to their strategy of denying risks and manipulating information and as a result they are confronted with massive distrust from their relevant publics.

If tobacco companies cannot even comply with the minimum CSR criterion of primum non nocere (Drucker, 1973, p. 368), how can they ever achieve the status of good citizenship and social responsibility? We will address that question in our paper by outlining CSR challenges facing the tobacco industry. We will develop the argument that the specific characteristics of the industry leave no room for public acceptance and corporate reputation as it is normally targeted by corporations in other industries. As a consequence, CSR in the tobacco industry must be conceptualized differently from the mainstream understanding of the debate.

The rest of the paper is organized as follows: In the next two sections we give a rough sketch of the two problematic dimensions of the tobacco industry, the lethal character of its products and the past behavior of its representatives. We then describe the limits to CSR in the tobacco industry as emerging from these two problems. In the following section we outline the assumption that the recent discovery of CSR in the tobacco industry contrasts with numerous ethically problematic patterns of behavior that still seem to link the industry to its "dark ages", thus fueling the deep distrust towards tobacco companies. However, there are even some signs of authentic changes within the industry which we are also going to sketch. In the concluding part, we outline a CSR approach for the tobacco industry which is built upon a much thinner approach than conceptualized in the mainstream debate.

\section{The killing fields of tobacco}

The first scientific case-control study on health effects of tobacco use was published by the German epidemiologist Franz H. Müller (1939), establishing a positive relationship between lung cancer and cigarette smoking. But his study was widely ignored due to historical circumstances (Doll, 2001). It was not until 1950 that the scientific landscape changed when the British Medical Journal published a landmark case-control study by Doll and Hill (1950). Studying the smoking habits of doctors they found a clear positive relationship between smoking and lung cancer. This study was followed by four decades of reports demonstrating that smoking had been by far the most important cause of lung cancer amongst the studied populations. After a decade of intensified research, the report by the U.S.-Surgeons General in 1964 stated that "cigarette smoking contributes substantially to mortality from certain specific diseases and to the overall death rate" (U.S. Department of Health, Education, and Welfare, 1964, p. 31). The report caused a nationwide debate on television, radio and in the press on tobacco smoking and inhalation and its effects (Lanfranco, 1970). Additionally, Domino (1973) concluded that nicotine is an addictive substance, followed by Russell (1974, p. 254) who emphasized "the crucial role of nicotine in the generation and maintenance of cigarette dependence, the 'potency' of which ensures that almost anybody who smokes at all becomes dependent".

Today, after 70,000 scientific articles having been published it is an acknowledged fact that nicotine is a physiologically active, addictive substance and that tobacco consumption is a major threat to public health (U.S. Department of Health and Human Services, 1988; WHO, 1999, 2002). Tobacco smoking and tobacco smoke cause more than 40 often lethal diseases (Doll, 2000; International Agency for Research on Cancer, 2002). Voluntary as well as involuntary smoking, also called secondhand or "environmental" tobacco smoke, is carcinogenic (International Agency for Research on Cancer, 2002). Women are additionally endangered 
as maternal smoking is harmful during pregnancy and has long-term effects on the baby after birth (WHO, 2002). Today, the WHO (2002, p. 36) states that "cigarettes kill half of all lifetime users" and estimates that deaths related to tobacco will rise from about four million a year in 1998 to about 10 million a year in 2030 (WHO, 1999). While consumption is decreasing in developed countries, consumption in developing countries is increasing by about $3.4 \%$ per annum (WHO, 1999) causing expected mortality to rise significantly. Health damages of tobacco have also a high economic impact on national economies. For Germany, it is estimated that tobacco consumption is responsible for $1.4 \%$ of all labor costs, as a result of lower net labor productivity and higher social security contributions (Deutsches Krebsforschungszentrum, 2003). In 1999, it accounted for $6 \%$ of all health care expenditures in the U.S. (WHO, 2002). By comparing mortality, morbidity, and health costs to benefits to consumers and producers, the WHO (1999) estimates that tobacco causes a worldwide net economic loss of 13.6 million dollars per year. This figure clearly contradicts the most basic argument advanced by the tobacco industry: the wealth creation its activity provides to society via employment and taxes. Despite all the negative effects, the production of cigarettes has increased. For example between 1994 and 1997 it increased by $26 \%$.

\section{The dark ages of the tobacco industry}

When the tobacco industry realized that the studies proving the health damages of tobacco consumption were becoming a threat to their very existence, they started to foster research that cast doubt upon the addictive character of nicotine and research that associated lung cancer with anything but smoking. In 1953, the presidents of the major tobacco companies met with the public relations company Hill \& Knowlton in order to engage in a massive, longterm public relations campaign "positive in nature and (...) entirely 'pro-cigarettes' " (Goss, 1953, p. 2). For this purpose, the tobacco companies founded institutes like the Tobacco Institute in Washington (1958) to do research in favor of the tobacco industry and lobby for their interests. They paid 'independent' scientists for their tobacco-friendly research (Burch, 1978; McDonald, 1982; Sterling, 1975). An early example of the counter-argumentation used was the claim of Fisher (1957) that there was a genetic predisposition to smoke and to have lung cancer. Therefore giving up cigarettes, would not prevent cancer as risk was genetically determined. Furthermore, tobacco companies provided grants to researchers that tried to prove that former studies were grounded on unscientific methods or poor statistical techniques. Criticisms included that populations were not randomly selected, populations were not representative, interviewers were not experienced, and that participants were biased by "self selection" (TIA, 1985; BAT, 1994). In later reports they claimed that warnings were not justified due to insufficient evidence; they accused governments of being prohibitionists, and argued that for democratic countries, coercion was intolerable (BAT, 1994; Chapman and Carter, 2003). For decades the industry engaged in massive lobbying and misinformation campaigns publicly claiming to question the scientific evidence. Their clear aim was to protect themselves against liability claims brought forward by affected customers and to avoid government regulation (Glantz et al., 1996). Moreover, tobacco companies consistently denied the adverse effects of tobacco, especially via passive smoking (Yach and Bialous, 2001). Having identified the WHO as the major enemy in their global fight to sell their products, tobacco companies deliberately subverted the tobacco control efforts of the WHO for many years (Zeltner et al., 2000).

The industry clearly targeted teenagers as the main target market, well knowing that by creating early addiction, they would probably be faithful consumers of their brand. As far back as the 1970s, Philip Morris knew that its best selling Marlboro brand was teenagers' favorite choice (Cummings et al., 2002, i7). Internal statements from the early 80 s show the industry's marketing focus: "Today's teenager is tomorrow's potential customer, and the overwhelming majority of smokers first begin to smoke while still in their teens" (Johnston et al., 1981, p. 1).

In 1966, U.S. tobacco companies were mandated to introduce the first warning statement on cigarette packs worldwide: "Caution - cigarette smoking may be hazardous to your health" (Chapman and Carter, 2003) but already in 1970, the U.S. Department of 
Health Education and Welfare found that warnings did not effect cigarette consumption. This motivated the U.S. Federal Trade Commission (2000) to eliminate tobacco broadcast advertising from January 1, 1971 on. In 1992 the European tobacco industry adopted the health warnings proposed by the European Economic Community (EEC) to avoid further sanctions (Chapman and Carter, 2003). However, as the British Medical Association (1999, p. 6) notes, "in the absence of warnings imposed by government, the tobacco industry fails to disclose even the most basic information on the health risks of smoking".

The strategy of manipulation and misinformation culminated in the appearing of seven tobacco company CEOs in a U.S. Congressional hearing, testifying that nicotine is not addictive. In the early 1990s tons of internal papers revealed that the companies had been well aware for decades of the lethal and addictive character of smoking. Consequently, there is a deep and probably long lasting public distrust towards the industry's activities and communication.

\section{CSR and the search for organizational legitimacy}

In recent years corporations have been confronted with ever rising expectations from their societal environment (Matten and Crane, 2005). Especially transnational corporations assume responsibilities that once were regarded as a governmental domain: public health, education, social security, human rights protection, illiteracy, malnutrition, Aids, homelessness, just to mention a few examples of the expanding corporate non-business activities (Margolis and Walsh, 2003; Matten and Crane, 2005). With farsightedness, Peter Drucker already described the changing role of business in society in the early 1970s. CSR "demands that business takes responsibility for social problems, social issues, social and political goals beyond their core business activities" (Drucker, 1973, p. 315). Corporate responsibility goes beyond the compliance with the legal and basic moral rules of society. As members of society, corporations have to take into account the common good and to improve societal welfare (Kok et al., 2001). Corporations can demonstrate to their stakeholders that they are "doing the right thing" through their CSR engagement (Joyner and Payne, 2002, p. 299). CSR normally aims at legitimizing a corporation's activities and increasing corporate acceptance. The preservation of societal acceptance is the main driving force of CSR activities (Weaver et al., 1999). Accordingly, corporate legitimacy has been described as the "yardstick" for the CSR discussion (Sethi, 1975; see also Carroll, 1979; Maignan and Ferrell, 2000; Wartick and Cochran, 1985). Suchman (1995, p. 574) defines legitimacy as "a generalized perception or assumption that the actions of an entity are desirable, proper or appropriate within some socially constructed system of norms, values, beliefs, and definitions". The following section will discuss selected aspects of CSR against the background of its legitimacy aspect since we expect it to be the main vulnerability of tobacco CSR. It is the societal acceptance dimension of CSR that constitutes the differences between the mainstream approach and the particular situation in the tobacco industry. We assume that due to the lethal character of smoking and the past behavior of tobacco companies, some key issues of CSR simply do not work the normal fashion. In the following, we will shortly discuss the limits of four issues that are normally regarded as important for achieving societal legitimacy through CSR engagement: corporate philanthropy, stakeholder collaboration, CSR reporting, and self-regulation activities. The discussion will demonstrate that these central aspects of the mainstream approach to CSR are ineffective or even counterproductive in the tobacco industry.

\section{The limits to CSR in the tobacco industry}

(1) Corporate philanthropy is a core aspect of CSR. Doing good and giving back to society sometimes is even conflated with CSR or citizenship behavior itself (discussed by Matten and Crane, 2005; as a recent example: Porter and Kramer, 2002). For tobacco companies, a philanthropic approach to CSR runs into several constraints. A first constraint might be called the "dirty money" problem. The decision to contribute to charities is constrained by the public pressure on those who take money from tobacco companies. When BAT gave money to the University of Nottingham for the foundation of a 
CSR research center, they provoked a furious debate within and around the University (Maguire, 2000). Similarly, it caused a public outcry when it became known that BAT offered to sponsor students at the London School of Hygiene and Tropical Medicine (Meikle, 2002). In Hungary, BAT became the center of attention of health advocates when it announced its substantial strengthening of the sponsorship of the University of Pécs that made it the principal sponsor of the second largest university of the country (Simpson, 2005). Western Michigan University was heavily criticized by Campaign for Tobacco-Free Kids for its decision to honor Philip Morris USA Inc. as its employer of the year (Prichard, 2004). Ethical Corporation magazine dropped Philip Morris as a possible sponsor for a corporate ethics conference in Hong Kong in October 2004 because two participants retreated in protest (Sydney Morning Herald, 2004). For tobacco companies, the number of potential beneficiaries of corporate philanthropy is considerably limited.

A second constraint in the philanthropy context might be called the "strategy dilemma". In the current, debate it has been argued that corporations should choose a strategic approach to philanthropic engagement. A strategic approach is characterized by two aspects: The philanthropic engagement should be based upon core competencies and it should be used for improving corporate reputation (Porter and Kramer, 2002). Core competencies are for instance behind the CSR engagement of Deutsche Bank, Microsoft or Merck \& Co. The Deutsche Bank has started to engage in the micro credit business building upon their banking competency. Microsoft is focusing its CSR engagement on IT education and lifelong learning. Merck \& Co have built upon their research expertise and developed a drug against river blindness, distributing the drug free of charge and treating around 25 million people each year in developing countries. For tobacco companies a strategic approach to corporate giving is difficult to implement since the specific characteristics of its products do not allow for a focus on core competencies. The reputational aspect is quite problematic as well, since there might be even more pressure on the charity organization if the tobacco company decides to launch a cause-related marketing campaign around their engagement. Accordingly, a tobacco corporations' ability to improve their "competitive context" through acts of philanthropy (Porter and Kramer, 2002 , p. 58) is considerably limited. A philanthropic doing-good strategy can neither build upon the business core competencies nor be used for marketing without provoking strong reactions of indignation. Indeed, even if they engage in causes that are distant from their own business (e.g. Philip Morris donating money to the fight against domestic violence), tobacco companies might also provoke public resistance since the whole engagement might be suspected to be an act of window dressing, with the intention to blur intrinsic ethical problems of the industry and its products.

(2) Stakeholder collaboration has been identified as a main pillar of a credible CSR engagement. Corporate societal engagement should be based upon close collaboration within the stakeholder network (e.g. Calton and Payne, 2003; Swanson, 1999; Wicks and Freeman, 1998). Collaboration not only leads to greater credibility of CSR activities, it furthermore promises positive effects on reputation. Collaboration with highly reputed organizations entails reputation spill-overs (Zimmerman and Zeitz, 2002). In the tobacco industry, the contrary can be expected. Collaboration with external partners is limited by the reputational risks for those who cooperate with tobacco companies. This is especially true in the field of scientific research which is of paramount importance for tobacco companies. Scientific research that is sponsored by tobacco companies is exposed to conflicts of interest and will unavoidably taste of manipulation (Kaufman et al. 2004). This can be seen in the fact that some scientific journals do not even publish research that is funded by the tobacco industry (Ong and Glantz, 2001). Being paid by the tobacco industry or cooperating with it threatens the reputation of the external partner, especially for cooperating scientific researchers or critical NGOs. There are two recent examples that demonstrate this. The collaboration between Philip Morris and Ragnar Rylander, an environmental medicine professor in Gothenburg whose research dealt with the health effects of passive smoking and who has been accused of scientific fraud (Tallmo, 2002). The donations of several tobacco companies to the environmental grassroots movement KAB (Keep America Beautiful) equally illustrate this phenome- 
non (Lamb, 2001). Collaboration is additionally limited because some of the most important stakeholders refuse to interact with representatives of the tobacco industry. It is precisely those potential partners with outstanding credibility such as the WHO that do not cooperate. On the contrary, they try to maintain arm's-length relationships with the industry (Ong and Glantz, 2001). For some actors in the tobacco stakeholder network, Freeman's (1997) "principle of limited immortality" is not acceptable. Being on a crusade against smoking, the continued existence of the corporations is not in the interest of leading NGOs. It is beyond the scope of this article to discuss the behavior of anti-tobacco activism even if their behavior might also provoke some critical questions. Some NGOs such as Ash or Tobaccofreekids refuse to talk to tobacco companies, some institutions, such as the WHO are at least very reluctant to talk to them in public. Anti-Tobacco NGOs often have no vision beyond the destruction of their counterparts. However, smoking is legal and a lot of people around the world smoke. Prohibition has not proved effective, on the contrary, it has clearly brought to the surface and exposed the unintended consequences of criminalizing drugs. Even extremely critical NGOs can not wish that controllable companies such as BAT or Philip Morris give their business to uncontrollable Mafia organizations that certainly would replace them. Irrespective of this, it seems that for tobacco companies, CSR must be pursued in coerced isolation from a large part of its relevant publics.

(3) In their CSR reporting, corporations normally focus on the positive effects of their engagement, sometimes with smaller aspects of self-critique (in the form of "what remains to be done"). If the social reporting of a tobacco company follows that mainstream approach to CSR reporting, it will not increase its credibility but rather be regarded as the perfect example of window-dressing. The first CSR report in the tobacco industry was published by BAT. It has been criticized for concealing the central aspect of its business, the annual death of millions of people (Burton and Rowell, 2002). As long as corporate transparency is limited in such a way, the industry must live with the general suspicion as formulated by Tapscott and Ticoll (2003, p. 283): "Nobody in the business of cigarette manufacturing can be a truly open enterprise, because the product causes harm". Another particularity: While professional CSR reporting often helps companies to become attractive for socially responsible investment funds, in the case of tobacco companies this rarely happens. "The common denominator among the vast majority of ethical or social responsible investment policies and products is the exclusion of tobacco companies in their portfolios" (Yach, Brinchmann and Bellet, 2001, p. 191). The Zurichbased Sustainable Asset Management Fund (SAM) has come under attack for its decision to include BAT in the Dow Jones Sustainability Index (Burton and Rowell, 2002). It seems as if CSR reporting in the tobacco industry is much more delicate than in other industries. Tobacco companies can not simply adopt the standards and procedures of mainstream reporting. They have to develop a different and more radical form of transparency.

(4) Self-regulation has become a major activity of transnationally operating companies that come under public pressure. Self-regulation is already criticized in other industries but it is even less acceptable for relevant stakeholders in the cigarette market (Hammond and Rowell, 2001). Voluntary initiatives that normally result in specific codes of conduct and are monitored by the participating corporations themselves are often criticized to be mere acts of window-dressing. Without real transparency and third party control, it is often business as usual that takes place behind the veil of well-formulated ethical rules (Rondinelli, 2002). In their analysis of the Responsible Care Program in the chemical industry, King and Lenox describe how self-regulation without sanctions leads to opportunism. On the average, members showed no different behavior than nonmembers (King and Lenox, 2000). Corporate self-regulation often lacks transparency, accountability, and thus is deprived of any legitimacy. It is not astonishing that the WHO questions the motivation of the tobacco industry behind their decision to ban tobacco marketing aimed at children. "We have seen no evidence that tobacco companies are capable of self-regulation and we need to be alert to any new attempt to persuade us that this new effort will succeed" as the WHO general-director Gro Harlem Brundlandt argued (Rondinelli, 2002, p. 407). When BAT, Philip Morris and Japan Tobacco adopted an international voluntary code of marketing, financial analysts did not expect any influence 
on sales volumes. "According to a leaked memo from a tobacco analyst for Credit Suisse Group the voluntary initiative was simply a way 'to improve the tobacco industry's image" (Burton and Rowell, 2002).

Deeply rooted distrust that has grown over decades seems to be the leitmotiv of the described deviations from standard reactions to corporate social engagement. Therefore, one of the key ambitions of the tobacco industry is to distance itself from its own former behavior demanding that the public should judge it by its current actions and not by its past activities. They portray themselves as a reformed industry and CSR engagement as well as CSR rhetoric are key elements of this strategy. However, a lot of relevant audiences still do not trust tobacco corporations because they do not believe in a genuine rupture with the past. The discovery of CSR in the tobacco industry is suspected to blur the "real" intentions of the corporations, their hidden agenda of business as usual. And indeed, some patterns of behavior of tobacco companies give reason to distrust the authenticity of their CSR engagement.

In the following analysis we mostly refer to two players in the tobacco market, BAT and Philip Morris. This is due to the fact that they are the dominating corporate brands. Both are prominent figures in CSR rhetoric and engagement. Due to their market positions, their behavior shapes the public's perception of the whole industry. The behavior of the less-known brands in the shadow of those market leaders can often be expected to be worse but less documented by industry-critics. We will sometimes refer to "the" industry, being aware of the fact that such a generalization is justified only in some cases of industry-wide consistent patterns of activities and argumentation. Different players in the market show different levels of critical behavior. However, the generalization of our analysis might be justified by the fact that in their relevant network of anti-tobacco NGOs, all tobacco corporations are indeed perceived as a compact and homogenous group. They all act in each other's shadow. "Should anybody trust the tobacco industry?" (Hammond and Rowell, 2001, p. 3) will be the key question for the credibility and effectiveness of tobacco CSR in each single company. In the following, we discuss eight examples of current behavior in the industry that - at least for some major critics in civil society - seem to be proof of the unreformed continuation of past behavior.

\section{Unholy spirits from the past}

\section{The intact PR machinery}

Two (probably linked) observations raise the suspicion that the PR machinery of the old times is still intact. First observation: In 1999, Philip Morris USA spent $\$ 75$ million on charity and $\$ 100$ million for a marketing campaign on its charity engagement (Porter and Kramer, 2002). Second observation: To market their new image, they cooperate with PR companies such as Burson-Marsteller who were already a reliable partner in the dark ages of tobacco business. They were involved in the secret Whitecoat project that aimed at reduced regulation and increased social acceptability for smoking. When developing the European expansion of the Whitecoat project in 1994, Burson-Marsteller saw the need to "educate" the public and political decision-makers who in their view, were "vulnerable to activists' emotional appeals and press campaigns" (Rampton and Stauber, 2000). Regarding PR as a key CSR instrument is a dangerous misunderstanding, especially for corporations that already operate on a low level of public trust (Asforth and Gibbs, 1990).

\section{The sound science strategy}

In the same Whitecoat project in 1994, BursonMarsteller formulated the assumption that the mainstream scientific position is to follow the precautionary principle. This position demands that "even if a hypothesis is not 100 percent scientifically proven, action should be taken, e.g. global warming" (Rampton and Stauber, 2000). With the help of their PR partners, tobacco companies tried to establish a "sound science" debate based on "good epidemiology" that casts doubt upon broadly accepted scientific research on the link between smoking and cancer dismissing it as "junk science" (Ong and Glantz, 2001). The aim was to trivialize the risk of tobacco use and to influence public health policy (Yach and Bialous, 2001). Tobacco compa- 
nies have been criticized for applying the same strategy today to the problem of passive smoking (Hammond and Rowell, 2001, p. 47; Samet and Burke, 2001, p. 1742). The courtesy and tolerance campaign of BAT and their one-dimensional information policy concerning the risk of passive smoking as demonstrated in their CSR communication seems to play a well-known melody. In its 2002/2003 Social Report, BAT states that passive smoking "can be a source of annoyance to non-smokers and smokers alike and is considered by some public health authorities to be a health concern. We believe that the health effects have been overstated". In a hearing at the UK House of Commons, BAT stated that "it has become common usage to describe many pleasurable activities, which some people find hard to give up or prefer not to give up, as 'addictions'. People say they are addicted to particular foods, using the internet, taking exercise, watching certain television programs, or even to working" (United Kingdom Parliament, 2000). This is the same double speaking junk science strategy that formerly was applied to the health effects of smoking.

\section{Hidden marketing activities}

Anti-tobacco activists argue that the more the explicit marketing activities for tobacco are reduced, the more hidden measures are taken to influence smokers. One striking example is the use of tobacco in Hollywood movies. Contrary to the 1998 Master Settlement Agreement between 46 U.S.-American states and the tobacco industry, the use of tobacco "in the most popular youth-oriented movies has actually increased by 50 percent" ( $\mathrm{Ng}$ and Dakake, 2002). Though not necessarily being the result of conspirative activities by tobacco corporations themselves, such revelations discredit not only the authenticity of tobacco CSR; They also subvert the corporations' official position to underage smoking.

\section{Involvement in criminal acts}

Tobacco companies have long been suspected for being involved in criminal activities such as the contraband sale of cigarettes. Internal documents demonstrate that even before the early 1990s some companies were involved in smuggling and most of them knew about cigarette smuggling without taking measures against it (ASH, 2000; Tobaccofreekids, 2004a). On January 14, 2003 the German customs officials searched the headquarters of the German Imperial Tobacco subsidiary Reemtsma suspecting the evasion of taxes and involvement in smuggling from the former Soviet Union to the EU and particularly Germany. Managers were accused of having actively encouraged criminal activities to undermine German tax policies (BBC, 2003). Accusations were supported by the statement of an arrested cigarette smuggler who said that in 1995 alone, $€ 0.6$ million of cigarettes of Reemtsma's (luxury) brand Davidoff were exported to Mongolia even though it was well known that nobody would smoke them there. Similarly, the Russian army was supplied with far more cigarettes than their possible demand could have been at this time (Die Welt, 2003).

\section{Political lobbying}

Good corporate citizenship has to do with transparency and accountability. The backdoor bargaining conspiracy represents the attempt to influence political decision-making without the public being involved and informed. In the past, tobacco companies have invested a lot of money and energy in lobbying against regulations. In Australia for instance, tobacco companies delayed the implementation of health warnings concerning addiction (Chapman and Carter, 2003). Similarly they have been lobbying against tax increases and advertisement bans in developing countries (Whist, 1986). Today, tobacco companies are accused of the continuing of their anti-regulation lobbying. As shown by the NGO Tobacco-free Kids "since 1999, the tobacco companies have spent more than $\$ 101$ million on lobbying the U.S. Congress" (Tobaccofreekids, 2004b). Lee and Glantz (2001) describe the industry's efforts to control tobacco policy making in Switzerland. A progressive understanding of CSR is incompatible with any kind of hidden political lobbying. Companies that are experts in backdoor bargaining are hardly accepted as partners in dialogue. Distrustful anti-tobacco activists regard 
the current controversy around smoking not as "the result of honest people who simply have different views, but a carefully and expensively orchestrated campaign by tobacco companies determined to put profit before life" (Hammond and Rowell, 2001, p. 3).

\section{Position on tax increases}

A recurrent argument used by the tobacco industry is that tax increases do not reduce smoking but instead encourage smuggling and increase the consumption of roll-your-own cigarettes, cheaper brands or counterfeit cigarettes (BATM, 2003). There are some good arguments that support this thesis. Evidence from the Canadian market indicates that the market for cigarettes is predominantly price driven and the main drivers are the various federal and/or provincial taxes (CISC, 2002). When Canada substantially increased excise taxes on cigarettes in the late 1980s and early 1990s, the black market exploded. By 1994, it was estimated that nearly $40 \%$ of Canada's cigarette market was being supplied through smuggling, causing an annual loss of nearly $\$ 2$ billion in tax revenues (U.S. House of Representatives Committee on Commerce, 1998). The Canadian Government then decided to sharply reduce taxes and was able to successfully cut down the market for contraband cigarettes again. However, the same Canadian study and numerous other scientific studies show another effect of tax increase which is largely ignored in the industry's statements: the reduction of smoking. Tax increases can reduce smoking, especially among low-income teenagers (Biener et al., 1998; Tauras et al., 2001; Scollo et al., 2003) and among pregnant women (Ringel and Evans, 2001). For those who already distrust in the authenticity of the social responsibility rhetoric, the strategic interest behind the industry's one-sided argumentation against tax increase is only too obvious. In an internal 1987 memo Philip Morris managers already described what they officially denied: "The problem with tax increase is that it does decrease consumption, just as ... the social engineers posing these increases want to see" (quoted in Hammond and Rowell, 2001) The same suspicion for a hid- den agenda can be provoked by some tobacco companies' arguments against the international convention on tobacco control, namely the argument that it would undermine the autonomy of national governments (Burton and Rowell, 2002).

\section{Powerless anti-smoking initiatives}

By the 1990s, tobacco companies were already engaged in youth smoking prevention programs. Philip Morris International BAT, and Japan Tobacco International financed more than 120 Youth Smoking Prevention programs in more than 70 countries as stated on the BAT website. The results are debatable. In a comparison between the American Legacy Foundation's "Truth" campaign and Philip Morris' "Think. Don't Smoke" campaign, Farrelly et al. show that the independent truthcampaign positively influences youths' attitude against smoking while the think-campaign has a rather counterproductive influence. The thinkcampaign improves the image of tobacco industry (Farelly et al., 2002). In another study, Landman et al. (2002, p. 925) criticize that industry-sponsored anti-smoking initiatives "do not implement the strategies that have been demonstrated to influence youth smoking: aggressive media campaigns that denormalize tobacco use and stress the industry's dishonesty". They position smoking as an adult activity thus increasing the desire to smoke. The anti-smoking initiatives of the industry might provoke the impression of a hidden agenda.

\section{Consumer vulnerability in the new markets}

Eastern Europe and Asia are the growth markets for the tobacco industry. In these regions, tobacco companies are confronted with serious ethical challenges. Consumers in developing countries are far more vulnerable to marketing practices than experienced consumers in western countries. They have less access to information about the dangers of smoking and in many cases are even illiterate. They might equate the desired modern lifestyle and western values with smoking (Amine, 1996). Furthermore, women might 
regard smoking as a symbol of emancipation. In industrialized countries, the growth rate of smoking among women at the beginning of the 20th century was clearly related to their public role and status (Schudson, 1984). The same is about to happen in the under-developed world (WHO, 1992). The tobacco companies operating in Africa, Asia or Eastern Europe try to take advantage of these specific market conditions and often refuse any special treatment for specific target groups thus trying to seduce as many smokers as possible. In Nigeria, BAT is for instance currently realizing an expensive, nationwide promotion campaign called "Collect II" for its famous brand Rothmans, officially targeting young men between 25 and 35 (Okonkwo, 2004). Consumer vulnerability in the new markets will be a key ethical issue in the industry and the authenticity of its CSR rhetoric will depend on how the corporations will deal with it.

Of course, there are some rays of hope on the horizon. In 2003, Philip Morris sued five importers along with nearly 1500 retailers accusing them of having delivered and sold more than 215,000 cartons of cigarettes including counterfeit Marlboros and other Philip Morris-brands (Gentile, 2003). In an effort to fight contrabanding and counterfeiting, Philip Morris International agreed on July 9, 2004 to make payments to the EU over a 12 year period totaling $\$ 1.25$ billion that may "serve as a source of additional funding for anti-contraband and anticounterfeit initiatives" (EU, 2004). The company has announced its intention to develop and implement a tracking and tracing system that makes its sales transparent in order to fight contraband cigarettes (EU, 2004). This promises to be an important step towards radical transparency in the tobacco industry. Similarly, BAT, Gallaher Ltd, and Imperial Tobacco signed agreements with the British HM Customs and Excise that are designed to reinforce cooperation in fighting tobacco smuggling into the UK (HM Customs and Excise, 2003). Another credible change may result from Philip Morris International's marketing code with its high standards of self-imposed limits to cigarette marketing. However, against the already discussed public distrust towards tobacco self-regulation, the code's credibility will depend on the clearly visible efforts to implement it and to act against code violations by company managers.

\section{Conclusion: CSR in the tobacco industry}

While CSR activities normally aim at gaining public respect, reputation or even admiration, tobacco companies have to accept that they are fighting on a different legitimacy battlefield. They are fighting for the mere right to exist. Tobacco industry finds itself on the lowest level of public acceptance and the lower the perceived legitimacy of a corporation the more skeptically its legitimation attempts will be observed by its relevant publics (Asforth and Gibbs, 1990). Our analysis demonstrates that mainstream CSR efforts will hardly contribute to legitimize tobacco companies. Obviously, societal acceptance has to do with some basic trustworthiness of the corporation. Starting from a very low level of trustworthiness, tobacco companies see their CSR efforts exposed to a much greater scrutiny and a much higher level of negative expectations than companies in other industries. As demonstrated, these negative expectations work against mainstream CSR aspects and they are partly confirmed by the seeming continuation of former patterns of behavior.

Can tobacco companies be good corporate citizens? Perhaps they can, but not by imitating mainstream ideas on CSR. Based on the terminology used in the leadership literature (Antonakis and House, 2002) and organizational trust discussion (Mayer et al., 1995) we propose distinguishing between three levels of CSR performance:

1. The instrumental level refers to a corporation's ability. The corporations dispose of the skills and competences that are necessary to deliver products or services in the quality expected by its customers.

2. The transactional level refers to a corporation's integrity. The corporation complies with the legal and moral rules of their societal context. Its transactions are transparent, its behavior is fair. It keeps its promises and acts with consistency.

3. The transformational level refers to a corporation's benevolence. The corporation demonstrates that it is willing to transcend self-interest for the sake of the common good. It contributes to the well-being of society.

Corporations that engage in CSR try to demonstrate that they operate on all three level of CSR perfor- 
mance with Carroll's fourth dimension of voluntary philanthropic cause engagement being the visible manifestation of self-interest transcendence (Carroll, 1991). CSR efforts of tobacco companies show the same motivation. However, the effort to expose themselves as benevolent actors rather nurtures their credibility problems instead of improving their legitimacy. As argued in the introduction, the interests of the tobacco industry run counter to the social good simply because tobacco kills. A CSR strategy at the level of benevolence is doomed to failure. For the time being, tobacco corporations for a large part of their relevant publics are not even credible on the second CSR level. Tobacco companies should abstain from any attempt to link their business to the common good. They should rather pursue an integrity-based CSR approach on the transactional level of their operations. Such a strategy at the level of integrity has to be built upon painful transparency and a clear and uncompromising rupture with the old business practices that spoil the perception of their authenticity. Of course, this leads to a much thinner concept of CSR as established in the theory discussion and corporate practice of other industries. In highly controversial industries such as tobacco harming the common good is probably more significant than the benefit to some consumers of the industry's products. As a consequence, corporations that operate in those industries need a different approach to CSR. Our concept of three levels of corporate societal performance may help to clarify the difference between a transactional and a transformational type of CSR. As the case of the tobacco industry demonstrated, there may be a glass ceiling between both levels that prevents companies from some industries from being perceived as contributing to the well-being of society. However, the conclusion would be wrong to deem those corporations as excluded from CSR practice in general. As we wish to demonstrate, those corporations have only to accept that their activities are limited to the transactional level.

If the integrity of business transactions is the focus of CSR, this has considerable consequences for corporate behavior. The main consequence: CSR in the tobacco industry must be transaction-driven. Our paper pleads for a transparent, dilemma-oriented approach to CSR along the tobacco supply chain. The critical public will at least expect a tobacco corporation to clearly describe its dilemmas and not to fall back into the old double speak (e.g. by reducing a dilemma to a morally mainstreamed but nevertheless hardly credible statement such as "our marketing activities only aim at adults who already are smokers of competing brands"). An honest description of all corporate dilemmas, from child labor in tobacco production to marketing activities in developing countries is the basic requirement in an industry with no credibility. The tobacco industry must thereby allow its critics to look deeply into its operations. The tobacco industry must abstain from any activities that might provoke even more distrust. Anti-tobacco advertising is for instance not the job of tobacco companies unless they adopt the effective strategies of their harshest critics. They may support it by money but should not decide upon the design. Tobacco companies will be measured by their efforts to install integrity across their supply chain. The credibility of tobacco CSR might for instance be propelled by the efforts to influence the behavior of (independent) cigarette retailers who play a key role in the control of underage access to cigarettes. The tobacco industry should stop all political lobbying activities and avoid cloudy scientific statements. They could even completely withdraw from issuing scientific statements at all and rather publish those of the WHO or other reliable sources on their websites and in their CSR reports. Tobacco companies should stop using philanthropic engagement for building reputation. Philip Morris may for instance continue the engagement against domestic violence, they may even continue to use this engagement for internal motivation and identification, but they should not publicly talk about it.

In some cases, integrity would even demand proactive behavior: Tobacco companies should make dilemmas transparent that are not yet in the public awareness. They should have a closer collaboration with governments to create effective tobacco regulation. They should do this in transparent discourses clearly accessible to civil society. They should engage (and some of them already do) in promoting transnational regulations and in the absence of those regulations, they should adopt the highest standards of tobacco regulation around the world on a voluntary and clearly accountable basis. A good corporate citizen in the tobacco industry has to develop and communicate a clear vision that leads 
beyond the established business practices. Corporate transformation, from a marketing to a research-driven company (safe cigarettes as main target), might be an element of such a vision.

In cases where moral dilemmas turn out to be unsolvable, good corporate citizenship can entail hazardous decisions. This might for instance be the case for the industry's marketing dilemma: Brand loyalty is established at a young age, but tobacco companies are not allowed to target teenagers. How can they avoid attracting teenagers or even children yet at the same time attract new customers with comparable loyalty effects? How can they avoid seducing non-smokers to start smoking? Unfortunately, the industry needs new clients since their old clients die early. It is an often used argument that marketing activities exclusively aim at attracting consumers of competing brands. However, this is a hardly credible statement. Advertising or sponsoring that portrays smoking as being fashionable unavoidably seduces non-smokers to start smoking. Marketing campaigns that aim at a target group of 25 to 35 year-old smokers are potentially attractive for non-smokers of the same age and definitely attract much younger non-smokers to follow their elder role models. It simply cannot be avoided. A good corporate citizen might consider to substantially reduce marketing activities in general even if the competitors do not follow.

Our paper aims at demonstrating that tobacco companies are not in the CSR business as it is becoming common place now across various industries and throughout academic research. As long as cigarettes kill active and passive users, all that a tobacco company can achieve is a reputation for transactional integrity. When tobacco companies try to link their activities to the common good, they indeed provoke the legitimate question whether tobacco and CSR are inherently contradictory. And as the short description of an integrity-driven CSR approach shows, even a much thinner idea of corporate responsibility will already lead to considerable changes for tobacco companies.

The discussion on CSR in the tobacco industry reveals the limits of the concept in extremely exposed industries. It might provide a valuable learning experience for those industries that risk being under comparable pressure at the future business ethics front-line: the food industry which will be linked to obesity or diabetes and the telecommunication industry that is threatened by the potential link between cancer and the use of mobile phones.

\section{References}

Action on Smoking and Health (ASH): 2000, 'Tobacco Industry Smuggling. Submission to the House of Commons Health Select Committee', http://www.ash. org.uk $/$ index.php? navState $=$ \&getPage $=$ http: $/ /$ www. ash.org.uk/html/./smuggling/html/smugglingbat.html, accessed July 29, 2004.

Amine, L. S.: 1996, 'The Need for Moral Champions in Global Marketing', European Journal of Marketing 30(5), 81-94.

Antonakis, J. and R. J. House: 2002, 'The Full-Range Leadership Theory: The Way Forward', in B. J. Avolio and F.J. Yammarino (eds.), Transformational and Charismatic Leadership: The Road Ahead (JAI, Amsterdam), pp. 3-33.

Ashforth, B. E. and B. W. Gibbs: 1990, 'The double-edge of organizational legitimation', Organization Science 1(2), 177-194.

British Broadcasting Corporation (BBC): 2003, 'Tobacco firm denies cigarette smuggling to Iraq', $B B C$ News (January 15), http://news.bbc.co.uk/1/hi/business/ 2659397.stm, accessed July 29, 2004.

Biener, L., R. H. Aseltine, B. Cohen and M. Anderka: 1998, 'Reactions of adult and teenaged smokers to the Massachusetts tobacco tax', American Journal of Public Health 88(9), 1389-1391.

British American Tobacco (BAT): 1994, 'Smoking Issues Claims \& Responses Active Smoking', Bates: 2504094459-2504094497.

British American Tobacco (BAT): 2003, 'Social Report 2002/03', http://www.bat.com/socialreport, accessed June 15, 2004.

British American Tobacco Malaysia (BATM): 2003, 'Taxation and Enforcement Against Illegal Cigarettes', Press Release (September 12), http://www.batmalaysia.com/CorporateInformation/PressRelease/2003/ 030912.htm, accessed July 29, 2004.

British Medical Association (BMA): 1999, Submission of the British Medical Association to the Health Committee Enquiry into the Tobacco Industry. (British Medical Association, London).

Bruno, K.: 2000, 'BP: Beyond Petroleum or Beyond Preposterous, Special to CorpWatch, http://www. corpwatch.org/article.php?id=219, accessed March 29, 2005. 
Burch, P. R. J.: 1978, 'Smoking and lung cancer: The problem of inferring cause', Journal Of The Royal Statistical Society 141(4), 437-477.

Burton, B. and A. Rowell: 2002, 'British American Tobacco's Socially Responsible Smoke Screen', PR Watch 9(4). http://www.prwatch.org/prwissues/ 2002Q4/bat.html, accessed August 12, 2004.

Calton, J. M. and S. L. Payne: 2003, 'Coping With Paradox', Business \& Society 42(1), 7-42.

Carroll, A. B.: 1979, 'A Three-Dimensional Conceptual Model of Corporate Performance', Academy of Management Review 4(4), 497-505.

Carroll, A. B.: 1991, 'The Pyramid of Corporate Social Responsibility: Toward the Moral Management of Organizational Stakeholders', Business Horizons 34(4), 39-48.

Criminal Intelligence Service Canada (CISC): 2002, Annual Report 2002. (Criminal Intelligence Service Canada, Québec).

Chapman, S. and S. M. Carter: 2003, 'Avoid Health Warnings on All Tobacco Products for Just as Long As We Can: A History of Australian Tobacco Industry Efforts to Avoid, Delay and Dilute Health Warnings on Cigarettes', Tobacco Control 12(Suppl III), iii13-iii22.

Cummings, K. M., C. P. Morley, J. K. Horan, C. Steger and N.-R. Leavell: 2002, 'Marketing to America's Youth: Evidence from Corporate Documents', Tobacco Control 11(Suppl I), i5-i17.

Deutsches Krebsforschungszentrum: 2003, Gesundheit fördern - Tabakkonsum verringern: Handlungsempfehlungen für eine wirksame Tabakkontrollpolitik in Deutschland. (Deutsches Krebsforschungszentrum, Heidelberg).

Die Welt: 2003, 'Ex-Schmuggler Belasten Reemtsma: Zigaretten über Osteuropa nach Deutschland zurücktransportiert', Die Welt (January 20).

Doll, R.: 2000, 'Review - Fifty years of research on tobacco', Journal of Epidemiology and Biostatistics, 5, 321-329.

Doll, R.: 2001, 'Commentary: Lung Cancer and Tobacco Consumption', International Journal of Epidemiology, 30, 30-31.

Doll, R. and A. B. Hill: 1950, 'Smoking and Carcinoma of the Lung: Preliminary Report', British Medical Journal, 2, 1271-1286.

Domino, E. F.: 1973, 'Neuropsychopharmacology of nicotine and tobacco smoking', in W. L. Dunn (eds.), Smoking Behavior: Motives and Incentives (V.H. Winston and Sons, Washington, D.C.), pp. 5-31.

Drucker, P.: 1973, Management Tasks, Responsibilities, Practices. (Harper and Row, New York).

European Union (EU): 2004, Anti-Contraband and AntiCounterfeit Agreement and General Release. (European Union, Brussels).

Farrelly, M. C., C. G. Healton, K. C. Davis, P. Messeri, J. C. Hersey and M. Lyndon Haviland: 2002, 'Getting to the Truth: Evaluating National Tobacco Countermarketing Campaigns', American Journal of Public Health 92(6), 901-907.

Fisher, R. A.: 1957, 'Alleged Dangers of Cigarette Smoking', Letters to the Editor of The British Medical Journal, vol. II, p. 43, 6 July 1957 and vol. II, pp. 297298, (August 3).

Freeman, R. E.: 1997, 'A Stakeholder Theory of the Modern Corporation', in L. P. Hartman (eds.), Perspectives in Business Ethics. (McGraw-Hill, Boston), pp. 171-181.

Gentile, G.: 2003, ‘Counterfeit Cigarettes', CBS Broadcasting Inc (June 10), http://www.cbsnews.com/stories/2003/06/10/national/main557799.shtml, accessed August 9, 2004.

Glantz, S. A., J. Slade, A. Lisa Bero, P. Hanauer and D. E. Barnes: 1996, The Cigarette Papers. (University of California Press, Berkeley, CA).

Goss, B. C.: 1953, Background Material on the Cigarette Industry Client, Minutes of Meeting, 15 Dec 1953, Hill \& Knowlton, Bates: 82106769-82106774.

Hammond, R. and A. Rowell: 2001, 'Trust Us: We're the Tobacco Industry', http://tobaccofreekids.org/ campaign/global/framework/docs/TrustUs.pdf, accessed August 6, 2004.

HM Customs and Excise: 2003, 'Annual Reports and Accounts 2002-03', 94th Report of the Commissioners of Her Majesty's Customs and Excise (December 18).

International Agency for Research on Cancer: 2002, 'Tobacco Smoking And Tobacco Smoke. Summary of data reported and evaluation', Monographs on the Evaluation of the carcinogenic risks to humans, Volume 83 (IARC, Lyon).

Johnston M., H. G. Daniel and C. J. Levy: 1981, 'Young smokers - Prevalence, Trends, Implications and Related Demographic Trends', Philip Morris Companies, Inc., Bates: 1000390803-1000390855 Exhibit 1.

Joyner, B. E. and D. Payne: 2002, 'Evolution and Implementation: A Study of Values, Business Ethics and Corporate Social Responsibility', Journal of Business Ethics 41(4), 297-311.

Kaufman, P. E., J. E. Cohen, M. J. Ashley, R. Ferrence, A. L. Halyk, F. Turcotte, K. L. Kyle and D. E. Stewart: 2004, 'Tobacco Industry Links to Faculties of Medicine in Canada', Canadian Journal of Public Health 95(3), 205-208.

King, A. A. and M. L. Lenox: 2000, 'Industry SelfRegulation Without Sanctions: The Chemical Industry's Responsible Care Program', Academy of Management Journal 43(4), 698-716.

Kok, P., T. V. D. Weile, R. McKenna and A. Brown: 2001, 'A Corporate Responsibility Audit within a Quality Management Framework', Journal of Business Ethics 31(4), 285-297. 
Lamb, W.: 2001, 'Keep America Beautiful: Grassroots Non-Profit or Tobacco Front Group', PR Watch 8(3), http://www.prwatch.org/prwissues/2001Q3/ kab.html, accessed August 12, 2004.

Landman, A., P. M. Ling and S. A. Glantz: 2002, 'Tobacco Industry Youth Smoking Prevention Programs: Protecting the Industry and Hurting Tobacco Control', American Journal of Public Health 92(6), 917-930.

Lanfranco, A.: 1970, 'Smoking and Disease', The St Luke's Hospital Gazette V(2), 181-186.

Lee, C.-Y. and Stanton A. Glantz: 2001, 'The Tobacco Industry's Successful Efforts to Control Tobacco Policy Making in Switzerland', Research Paper of the University of California, Center for Tobacco Control Research and Education, http://repositories.cdlib.org/ ctcre/tcmpi/Swiss2001, accessed August 12, 2004.

Maguire, K.: 2000, 'Dons Furious Over Tobacco Cash', The Guardian (December 6).

Maignan, I. and O. C. Ferrell: 2000, 'Measuring corporate citizenship in two countries: the case of the United States and France', Journal of Business Ethics 23(3), 283-297.

Matten, D. and A. Crane: 2005, 'Corporate Citizenship: Towards an Extended Theoretical Conceptualization', Academy of Management Review 30(1), 166-179.

Mayer, R. C., J. H. Davis and F. D. Schoorman: 1995, 'An Integrative Model of Organizational Trust', Academy of Management Review 20(3), 709-734.

Margolis, J. D. and J. P. Walsh: 2003, 'Misery Loves Companies: Rethinking Social Initiatives by Business', Administrative Science Quarterly 48(2), 268-305.

McDonald, E. J.: 1982, Statement, U.S. Congress, House Committee on Energy and Commerce, Subcommittee on Health and the Environment, 1982 Hearing, 97th Congress, Second session, March 5, 11 and 12, 1982 (Washington Printing Office, 1982), 669-684, Appendix.

Meikle, J.: 2002, 'BAT Sorry for Offer to Sponsor Student', The Guardian (October 11).

Michalos, A. C.: 1997, 'Issues for Business Ethics in the Nineties and Beyond', Journal of Business Ethics 16(3), 219-230.

Mitchel, N.: 1986, 'Corporate Power, Legitimacy, and Social Policy', The Western Political Quarterly 39(2), 197-212.

Müller, F. H.: 1939, 'Tabakmissbrauch und Lungencarcinom', Zeitschrift für Krebsforschung, 49, 57-85

Ng, C. and B. Dakake: 2002, 'Tobacco At the Movies. Tobacco Use in PG-13 Films', http://masspirg.org/ reports/TobaccoattheMovies.pdf, accessed July 28, 2004.

Ong, E. K. and S. A. Glantz: 2001, 'Constructing “'Sound Science" and "Good Epidemiology": Tobacco, Law- yers, and Public Relations Firms', American Journal of Public Health 91(11), 1749-1757.

Okonkwo, K.: 2004, 'Rothmas Brand: Enriching Nigerians Through Product Promotions', AllAfrica Global Media (August 5).

Porter, M. and M. R. Kramer: 2002, 'The Competitive Advantage of Corporate Philanthropy', Harvard Business Review 80(12), 57-68.

Prichard, J.: 2004, 'University defends Philip Morris accolade', Western Herald (October 20).

Rampton, S. and J. Stauber: 2000, 'How Big Tobacco Helped Create "the Junkman"” PR Watch 7(3), http// www.prwatch.org/prwissues/2000Q3/junkman.html, accessed July 27, 2004.

Rimmer, L.: 2004, 'BAT's Big Wheeze - The Alternative Report', http://www.ash.org.uk/html/conduct/pdfs/batbigwheeze.pdf, accessed on August 6, 2004.

Ringel, J. S. and W. N. Evans: 2001, 'Cigarette Taxes and Smoking During Pregnancy', American Journal of Public Health 91(11), 1851-1856.

Rondinelli, D. A.: 2002, 'Transnational Corporations: International Citizens or New Sovereigns?', Business and Society Review 107(4), 391-413.

Russell, M. A. H.: 1974, 'Realistic Goals for Making and Health', Lancet, I, 254-258.

Samet, J. M. and T. A. Burke: 2001, 'Turning Science Into Junk: The Tobacco Industry and Passive Smoking', American Journal of Public Health 91(11), 1742-1744.

Schudson, M.: 1984, Advertising, the Uneasy Persuation (Basic Books, New York).

Scollo, M., S. Younie, M. Wakefield, J. Freeman and F. Icasiano: 2003, 'Impact of Tobacco Tax Reforms on Tobacco Prices and Tobacco Use in Australia', Tobacco Control 12(Suppl II), 59-66.

Sethi, S. P.: 1975, 'Dimensions of Corporate Social Performance: An Analytical Framework', California Management Review 17(3), 58-64.

Simpson, D.: 2005, 'Hungary: BAT university deal questioned', Tobacco Control, 14, 76-77.

Sterling, T.D.: 1975, 'A critical re-assessment of the evidence bearing on smoking as the cause of lung cancer', American Journal of Public Health 65(9), 939953.

Suchman, M. C.: 1995, 'Managing Legitimacy: Strategic and Institutional Approaches', Academy of Management Review 20(3), 571-610.

Swanson, D. L.: 1999, 'Towards an Integrative Theory of Business and Society: A Research Strategy for Corporate social Performance', Academy of Management Review 24(3), 508-521.

Sydney Morning Herald: 2004, 'Business Ethics Forum Sponsor Dropped', Sydney Morning Herald (July 18). 
Tallmo, K.-E.: 2002, 'Philip Morris assigned secret grants to Swedish professor', http://www.nisus.se/archive/ 020610e.html, accessed August 12, 2004.

Tapscott, D. and D. Ticoll: 2003, The Naked Corporation. (Free Press, New York).

J. A. Tauras, P. M. O’Malley and L. D. Johnston: 2001, Effects of Price and Access Laws on Teenage Smoking Initiation: A National Longitudinal Analysis, NBER Working Papers 8331 (National Bureau of Economic Research, Inc, Cambridge, MA).

Tobaccofreekids: 2004a, 'The Big Cigarette Companies and Cigarette Smuggling', http://tobaccofreekids.org/ campaign/global/framework/docs/Smuggling.pdf, accessed August 6, 2004.

Tobaccofreekids: 2004b, 'Tobacco Industry Gave More Than \$2.2 Million in Federal Political Contributions So Far in the 2003-2004 Election Cycle', http://tobaccofreekids.org/Script/DisplayPressRelease.php3?Display= 779, accessed August 6, 2004.

Tobacco Institute of Australia (TIA): 1985, 'The Tobacco Industry's Position on Proposed New Rotating Health Warnings on Tobacco Products and Advertising', Bates: 2500009158/9187.

United Kingdom Parliament: 2000, 'Memorandum by British American Tobacco', http://www.publications. parliament.uk/pa/cm199900/cmselect/cmhealth/27/ 0011309.htm, accessed August, 06, 2004.

U.S. Department of Health, Education, and Welfare: 1964, Smoking and Health: Report of the Advisory Committee of the Surgeon General of the Public Health Service, Public Health Service Publication No. 1103 (U.S Department of Health, Education, and Welfare, Washington, D.C.).

U.S. Department of Health and Human Services: 1988, The Health Consequences of Smoking: Nicotine Addiction. A Report of the Surgeon General. (US Government Printing Office, Washington, D.C.).

U.S. House of Representatives Committee on Commerce: 1998, 'Top Law Enforcement Officers Warn of Growing Cigarette Smuggling by Organized Crime', Tobacco Policy 3 (U.S. House of Representatives Committee on Commerce, Washington, D.C).

Wartick, S. L. and P. L. Cochran: 1985, 'The Evolution of the Corporate Social Performance Model', Academy of Management Review 10(4), 758-769.
Weaver, G. R., L. K. Trevino and P. L. Cochran: 1999, 'Integrated and Decoupled Corporate Social Performance: Management Commitments, External Pressure, and Corporate Ethics Practices', Academy of Management Journal 42(5), 539-552.

Whist, A.: 1986, Memo to Board of Directors, Philip Morris International Corporate Affairs (December 17), Bates: 2025431401/1406.

Wicks, A. and R. E. Freeman: 1998, 'Organization Studies and the New Pragmatism: Positivism, Anti-Positivism, and the Search for Ethics', Organization Science 9(2), 123-149.

World Health Organization (WHO): 1992, Women and Tobacco: Moving from Policy to Action. (World Health Organization, Geneva).

World Health Organization (WHO): 1999, The World Health Report: Making a Difference. (World Health Organization, Geneva).

WorldHealth Organization, (WHO): 2002, The Tobacco Atlas (World Health Organization, Geneva).

World Health Organization (WHO): 2003, Tobacco Industry and Corporate Responsibility...an Inherent Contradiction. (World Health Organization, Geneva).

Yach, D. and S. A. Bialous: 2001, 'Junking Science to Promote Tobacco', American Journal of Public Health 91(11), 1745-1748.

Yach, D., S. Brinchman and S. Bellet: 2001, 'Healthy Investments and Investing in Health', Journal of Business Ethics 33(3), 191-198.

Zeltner, T. et al.: 2000, 'Tobacco industry strategies to undermine tobacco control activities at the World Health Organization', Report of the Committee of Experts on Tobacco Industry Documents (World Health Organization, Geneva).

Zimmerman, M.A. and G.J. Zeitz: 2002, 'Beyond Survival: Achieving New Venture Growth by Building Legitimacy', Academy of Management Review 27(3), 414-431.

Ecole des Hautes Etudes Commerciales (HEC), University of Lausanne,

619-BFSH-1, CH - 1015, Lausanne-Dorigny, Switzerland E-mails: guido.palazzo@unil.ch ulf_richter@gmx.de 